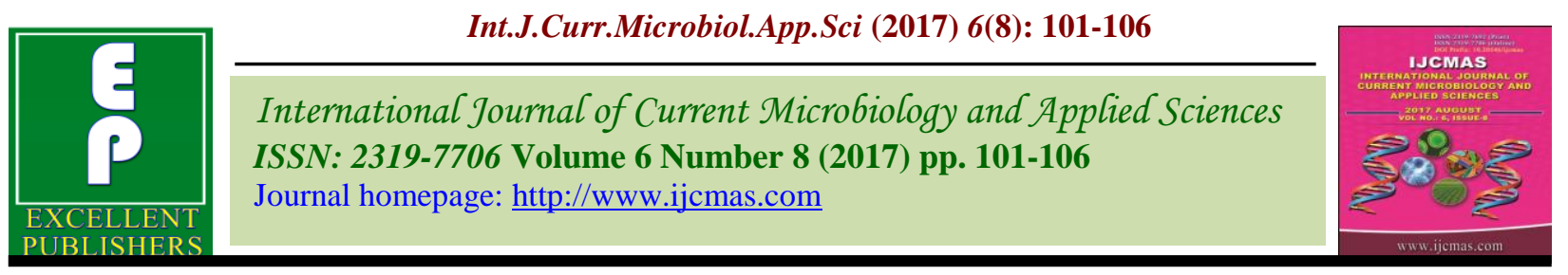

Original Research Article

https://doi.org/10.20546/ijcmas.2017.608.013

\title{
Seasonal Incidence and Management of Thrips, Scirtothrips dorsalis (Hood) Infesting Rose
}

\author{
Thanlass Norboo $^{1}$, Hafeez Ahmad ${ }^{1}$, Suheel Ahmad Ganai ${ }^{{ }^{*} \text {, Nadeya Khaliq }}{ }^{1}$, \\ Divya Chaand ${ }^{1}$, Stanzin Landol $^{2}$ and Sonika Sharma ${ }^{1}$ \\ ${ }^{1}$ Division of Entomology, Block No. 6, FoA, Main Campus, SKUAST-J, Chatha, \\ Jammu -180 009, J\&K, India \\ ${ }^{2}$ Division of Agroforestry, Block No. 4, FoA, Main Campus, SKUAST-J, Chatha, \\ Jammu -180 009, J\&K, India \\ *Corresponding author
}

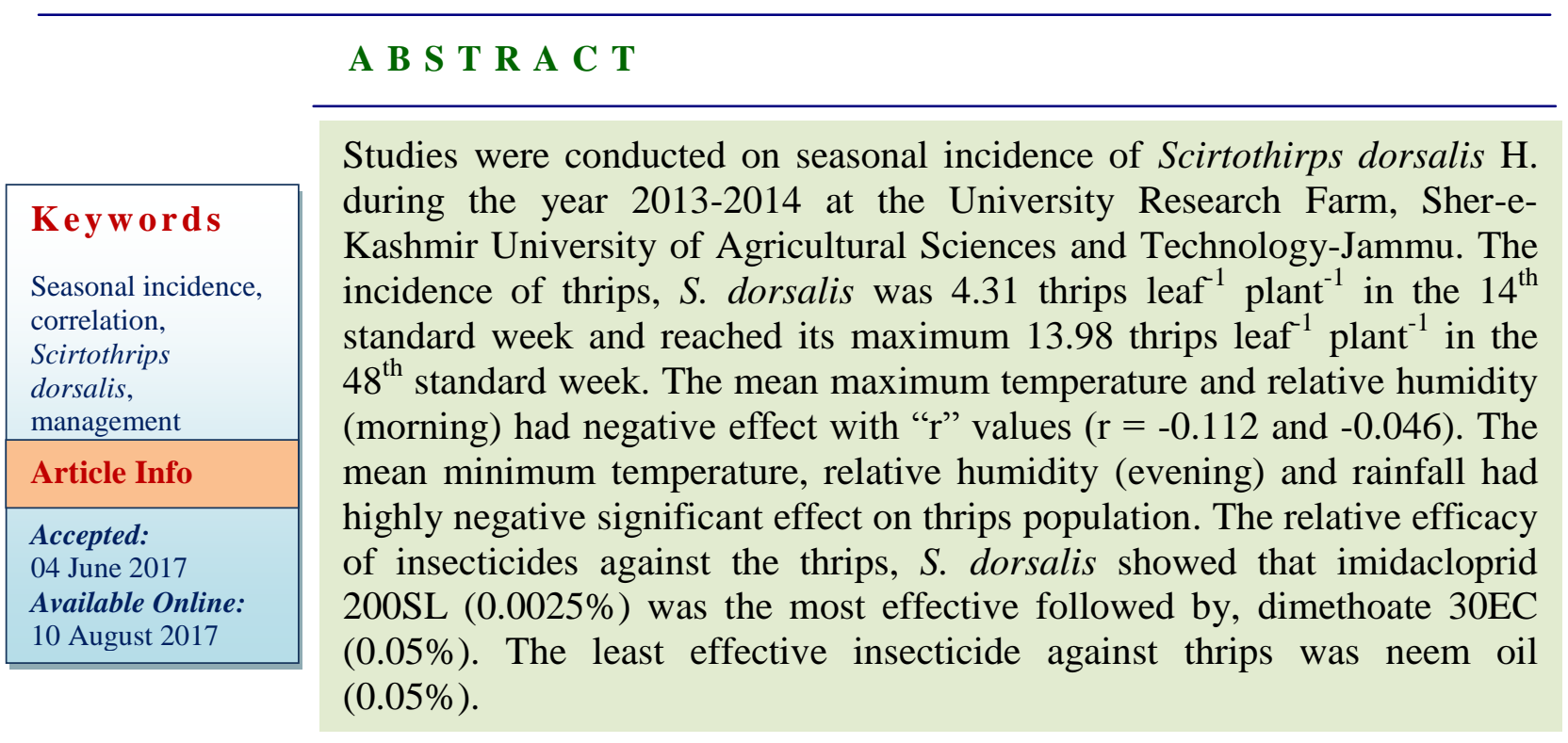

\section{Introduction}

Rose (Rosa sp.) is one of the nature's beautiful creations and is universally called as 'queen of flower'. The word rose is derived from the name 'Erose' meaning 'the god of love'. In Sanskrit literature, rose is referred as 'Tarunipushpa', Atimanjula' and 'Semantika'. Rose belongs to the family Rosaceae. The genus Rosa consists of about 120 species out of which only eight species are cultivated viz., Rosa chinensis (Jacq), Rosa damascene (Mill), Rosa foetida, Rosa gallica, Rosa gigantea, Rosa moschara, Rosa multiflora, and Rosa wischuriana. It is extensively grown in and around the cities of Delhi, Pune, Bangalore and Chandigarh. India has about 88,607 hectare of land under floriculture with a production of 6,80,600 tonnes of flowers (Anonymous, 2000). Cultivation of rose under protected conditions has gained importance in recent years due to its export potential. The rose thrips, Scirtothrips dorsalis (Hood) is also a serious problem on rose grown under 
protected cultivation. Both immatures and adults feed on tender and moderately matured leaves and developing flower buds by lacerating the tissue and sucking the sap. The feeding results in mottling, severe curling, browning and drying of tender leaves, sepals, tender stalks, outer petals of green and half opened buds turn to brown colour and appear as if they are burnt. Damaged flowers get discoloured and distorted in shape and reduced in size (Rani and Mohan, 1997). This pest can cause $28-95$ per cent damage with a population density of 11-33 thrips/flower (Gahukar, 2003). This pest is posing severe loss to the growers because some of the chemicals are causing phytotoxicity to the crop and some have a chance of causing resistance of this pest. At present, the information regarding the influence of weather parameters on the incidence of this pest, bioefficacy of newer molecules of pesticides, botanicals, mycopathogens is meagre. In Jammu \& Kashmir, no such work has been done on these aspects. Therefore, keeping in view the economic importance of the crop and the magnitude of the damage caused by the insect, the present study has been proposed.

\section{Materials and Methods}

Investigations were undertaken during 20132014 to study the seasonal incidence of thrips at University Research Farm, Sher-e-Kashmir University of Agricultural Sciences and Technology of Jammu. Rose variety "Rose Local" was raised with recommended agronomic practices in the plot size of $3 \times 1$ $\mathrm{m}^{2}$ with row to row and plant to plant distance of $45 \mathrm{~cm}$ and $20 \mathrm{~cm}$, respectively. Five randomly selected plants from the field were tagged for recording the observations. Observations on seasonal incidence were recorded at weekly intervals, starting from the first appearance $\left(14^{\text {th }}\right.$ standard week $)$ of thrips in the field. Thrips population was counted from five leaves each from top, middle and bottom and their average was taken. For the thrips management, a trial was laid out in the randomized block design with three replications. Six insecticidal formulations including control were tested as given below. Observations on the thrips population from the selected plants were recorded before and after 1,7 and 15 days of spray. Data thus obtained were analysed statistically and the efficacy of the insecticides were worked out.

T1- Neem oil@0.05\%

T2- Novaluran10EC @ 50g a.i/ha

T3- Carbosulfuran 25EC @ 0.03\%

T4- Imidachloprid 200SL @ 0.0025\%

T5- Dimethoate 30EC @ 0.05\%

T6- Control

\section{Results and Discussion}

\section{Seasonal Incidence of $\boldsymbol{S}$. dorsalis}

The data regarding seasonal incidence of thrips on rose during 2013-2014 (Table 1, Fig 1) revealed that incidence of thrips on rose leaves, commenced in $14^{\text {th }}$ standard week (4.31 thrips/leaf/plant) when mean maximum and minimum temperature, mean relative humidity (morning and evening) and rain fall were 31.45 and $13.95^{\circ} \mathrm{C}, 81.00$ and 32.00 per cent and $1.10 \mathrm{~mm}$, respectively. The thrips population ranged from 0.00 to 13.98 thrips/leaf/plant. The thrips population started increasing from $30^{\text {th }}$ ( 0.00 thrips/leaf/plant) to $48^{\text {th }}$ standard week (13.98 thrips/leaf/plant) and after that thrips population started decreased upto $12^{\text {th }}$ standard week (12.45 thrips/leaf/plant) when mean maximum and minimum temperature, mean relative humidity (morning and evening) and rain fall were 50.05 and $18.61{ }^{\circ} \mathrm{C}, 65.53$ and 34.67 per cent and $1.02 \mathrm{~mm}$, respectively. The thrips poulation reached its peak (13.98 thrips/leaf/plant) during $48^{\text {th }}$ standard week. Correlation matrix (Table 2) between seasonal 
incidence of thrips and prevailing weather factors revealed that maximum temperature and relative humidity (morning) had negative effect on the thrips population with ' $r$ ' values $(\mathrm{r}=-0.112$ and $\mathrm{r}=-0.046)$ and minimum temperature, relative humidity (evening) and rainfall had highly negative significant effect on thrips population with ' $r$ ' values $(\mathrm{r}=$ $0.581^{* *},-0.553^{* *}$ and $\left.-0.602^{* *}\right)$ respectively. Regression studies for the effect of abiotic factors on the build-up of thrips population was significantly influenced by weather factors, their contribution being 68.00 per cent during 2013-2014, respectively. Our results are in conformation with Park et al., (2002) who studied the incidence of Frankliniella occidentalis on rose cultivars under greenhouse condition and reported that the first detection of $F$. occidentalis was observed in early April, gradually increased until May and the greatest densities occurred during June. Similar results were reported by Gahukar (2003) and Satyanarayan (2006).

\section{Management of S. dorsalis}

\section{First spray}

Efficacy of the insecticides for the management of the pest revealed that all the insecticidal treatments at 1,7 and 14 days after spray were superior to control in reducing the pest population (Table 3). The observations recorded on $3^{\text {rd }}$ day after spray revealed that all the treatments proved significantly superior over control. Imidacloprid (7.92 thrips/leaf/plant) was found to be most effective treatment in reducing the thrips population which was at par with dimethoate (8.01 thrips/leaf/plant). The next best treatment was carbosulfuran (8.98 thrips/leaf/plant), novaluran (9.07 thrips/leaf/plant). Neem oil (9.63 thrips/leaf/plant) was found to be least effective against the thrips. The observations recorded on $7^{\text {th }}$ day after spray revealed that all the treatments proved significantly superior over control. Imidacloprid (4.67 thrips/leaf/plant) was found to be most effective treatment in reducing the thrips population which was at par with dimethoate (7.34 thrips/leaf/plant). The next best treatment was carbosulfuran $\quad(7.99$ thrips/leaf/plant $) \quad$ novaluran $\quad(8.56$ thrips/leaf/plant) and neem oil (9.21 thrips/leaf/plant). On $15^{\text {th }}$ day after spray revealed that all the treatments proved significantly superior over control.

Fig.1 Seasonal incidence of thrips, S. dorsalis Hood during 2013-2014

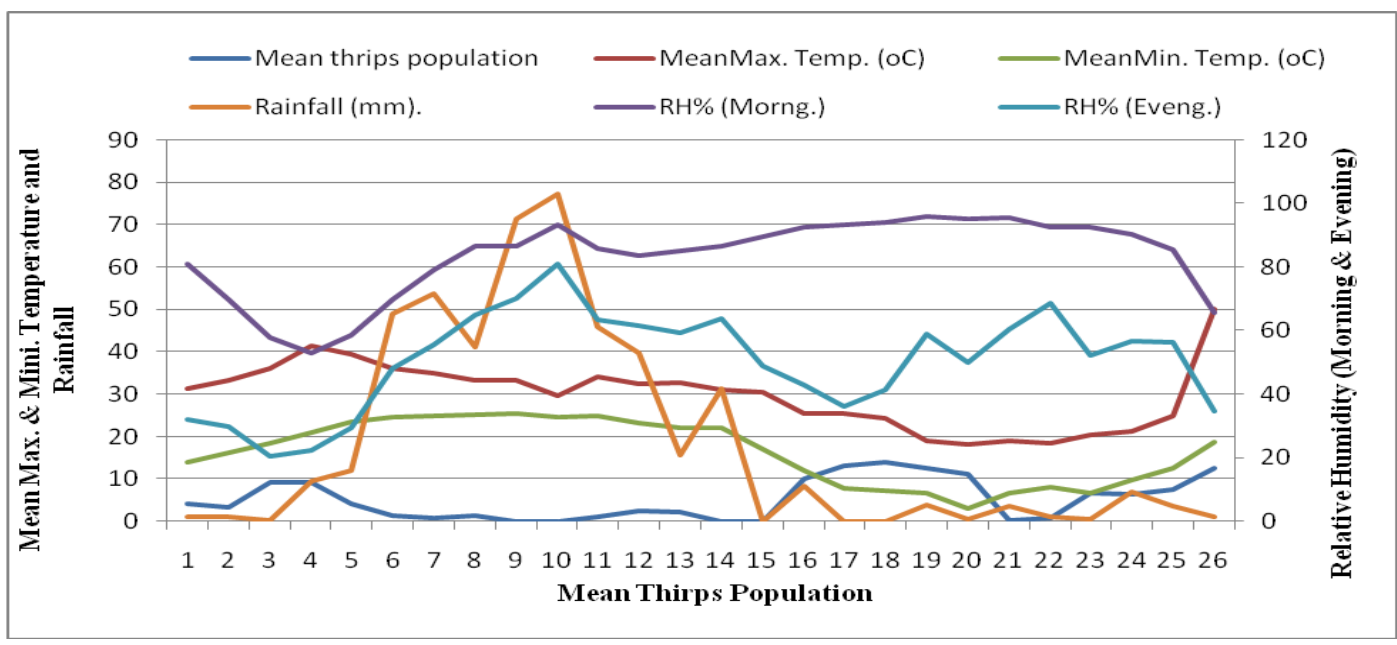


Table.1 Seasonal incidence of thrips, S. dorsalis population on rose during 2013-14

\begin{tabular}{|c|c|c|c|c|c|c|}
\hline Standard weeks & $\begin{array}{l}\text { Mean thrips } \\
\text { population }\end{array}$ & $\begin{array}{l}\text { Mean Max. } \\
\text { Temp. }\left({ }^{\circ} \mathrm{C}\right)\end{array}$ & $\begin{array}{l}\text { Mean Min. } \\
\text { Temp. }\left({ }^{\circ} \mathrm{C}\right)\end{array}$ & RH\% (Morng.) & RH\% (Eveng.) & Rainfall (mm). \\
\hline 16 & 3.46 & 33.15 & 16.20 & 70.00 & 30.00 & 1.20 \\
\hline 20 & 9.20 & 41.30 & 20.75 & 53.00 & 22.50 & 9.60 \\
\hline 22 & 4.32 & 39.50 & 23.25 & 58.50 & 29.50 & 12.00 \\
\hline 24 & 1.50 & 36.10 & 24.55 & 70.00 & 48.00 & 48.90 \\
\hline 30 & 0.00 & 33.30 & 25.30 & 86.50 & 70.00 & 71.55 \\
\hline 32 & 0.00 & 29.55 & 24.60 & 93.50 & 81.00 & 77.30 \\
\hline 34 & 1.00 & 34.10 & 24.70 & 86.00 & 63.50 & 46.00 \\
\hline 36 & 2.50 & 32.40 & 23.05 & 83.50 & 61.50 & 39.65 \\
\hline 38 & 2.29 & 32.70 & 21.95 & 85.00 & 59.50 & 15.55 \\
\hline 48 & 13.98 & 24.40 & 7.05 & 94.00 & 41.50 & 0.00 \\
\hline 50 & 12.56 & 19.00 & 6.55 & 96.00 & 59.00 & 3.90 \\
\hline 52 & 11.32 & 18.20 & 3.00 & 95.40 & 49.90 & 0.60 \\
\hline 02 & 0.15 & 19.10 & 6.50 & 95.80 & 60.60 & 3.70 \\
\hline 04 & 0.90 & 18.50 & 8.10 & 92.80 & 68.50 & 1.00 \\
\hline 06 & 6.78 & 20.30 & 6.50 & 92.70 & 52.40 & 0.70 \\
\hline 08 & 6.55 & 21.30 & 9.70 & 90.30 & 56.90 & 7.10 \\
\hline 10 & 7.68 & 24.90 & 12.40 & 85.40 & 56.50 & 3.70 \\
\hline 12 & 12.45 & 50.05 & 18.61 & 65.53 & 34.67 & 1.02 \\
\hline Range & 0.00-13.98 & 18.20-50.05 & $3.00-25.30$ & $53.00-96.00$ & $20.50-81.00$ & 0.00-177.30 \\
\hline Mean \pm SEm & $6.05 \pm 0.84$ & $29.85 \pm 1.55$ & $16.28 \pm 1.46$ & $83.09 \pm 2.50$ & $50.40 \pm 3.08$ & $22.30 \pm 7.44$ \\
\hline
\end{tabular}


Table.2 Correlation matrix showing relationship between thrips, S. dorsalis and Various abiotic factors during 2013-2014

\begin{tabular}{|l|lcccc|}
\hline & $\mathrm{X}_{1}$ & $\mathrm{X}_{2}$ & $\mathrm{X}_{3}$ & $\mathrm{X}_{4}$ & $\mathrm{X}_{5}$ \\
\hline $\mathrm{Y}_{1}$ & -0.112 & $-0.581 * *$ & -0.046 & $-0.553 * *$ & $-0.602 * *$ \\
\hline
\end{tabular}

$*$ Correlation is significant at 0.01 level

**Correlation is significant at 0.05 level

\section{Regression Model:}

$\mathrm{Y}_{1}=4.328+0.492 \mathrm{X}_{1}-0.904 \mathrm{X}_{2}+0.078 \mathrm{X}_{3}-0.146 \mathrm{X}_{4}+0.097 \mathrm{X}_{5}\left(\mathrm{R}^{2}=0.680\right)$

Where,

$\mathrm{Y}_{1}=$ Mean thrips population

$\mathrm{X}_{1}=$ Maximum temperature $\left({ }^{\circ} \mathrm{C}\right)$

$\mathrm{X}_{2}=$ Minimum temperature $\left({ }^{\circ} \mathrm{C}\right)$

$\mathrm{X}_{3}=$ Mean relative humidity morning $(\%)$

$\mathrm{X}_{4}=$ Mean relative humidity evening $(\%)$

$\mathrm{X}_{5}=$ Rainfall $(\mathrm{mm})$

Table.3 Efficacy of different insecticides against thrips population on rose during 2013-14

\begin{tabular}{|c|c|c|c|c|c|c|c|c|}
\hline \multirow{3}{*}{ Treatments } & \multicolumn{8}{|c|}{ Mean thrips population/leaf } \\
\hline & \multicolumn{4}{|c|}{$1^{\text {st }}$ spray } & \multicolumn{4}{|c|}{$2^{\text {nd }}$ spray } \\
\hline & 1DBS* & 1DAS* & 7DBS & 15DAS & 1DBS & 1DAS & 7DBS & 15DAS \\
\hline Neem oil & $\begin{array}{l}12.98 \\
(3.67)\end{array}$ & $\begin{array}{c}9.63 \\
(3.18)\end{array}$ & $\begin{array}{c}9.21 \\
(3.11)\end{array}$ & $\begin{array}{l}10.23 \\
(3.27)\end{array}$ & $\begin{array}{l}11.54 \\
(3.46)\end{array}$ & $\begin{array}{c}8.71 \\
(3.03)\end{array}$ & $\begin{array}{c}6.87 \\
(2.71)\end{array}$ & $\begin{array}{c}3.32 \\
(1.95)\end{array}$ \\
\hline Novaluran10 EC & $\begin{array}{l}12.77 \\
(3.64)\end{array}$ & $\begin{array}{c}9.07 \\
(3.09)\end{array}$ & $\begin{array}{c}8.56 \\
(3.00)\end{array}$ & $\begin{array}{c}9.81 \\
(3.21)\end{array}$ & $\begin{array}{l}10.76 \\
(3.35)\end{array}$ & $\begin{array}{c}6.67 \\
(2.67)\end{array}$ & $\begin{array}{c}3.45 \\
(1.98)\end{array}$ & $\begin{array}{c}2.56 \\
(1.74)\end{array}$ \\
\hline Carbosulfan 25 EC & $\begin{array}{l}12.54 \\
(3.61)\end{array}$ & $\begin{array}{c}8.98 \\
(3.07)\end{array}$ & $\begin{array}{c}7.99 \\
(2.91)\end{array}$ & $\begin{array}{c}8.32 \\
(2.95)\end{array}$ & $\begin{array}{c}9.57 \\
(3.17)\end{array}$ & $\begin{array}{c}4.56 \\
(2.24)\end{array}$ & $\begin{array}{c}2.34 \\
(1.68)\end{array}$ & $\begin{array}{c}1.12 \\
(1.27)\end{array}$ \\
\hline Imidachloprid 200SL & $\begin{array}{l}11.74 \\
(3.49)\end{array}$ & $\begin{array}{c}7.92 \\
(2.90)\end{array}$ & $\begin{array}{c}4.67 \\
(2.27)\end{array}$ & $\begin{array}{c}5.01 \\
(2.34)\end{array}$ & $\begin{array}{c}6.53 \\
(2.65)\end{array}$ & $\begin{array}{c}2.79 \\
(1.81)\end{array}$ & $\begin{array}{c}1.08 \\
(1.25)\end{array}$ & $\begin{array}{c}0.34 \\
(0.91)\end{array}$ \\
\hline Dimethoate $30 \mathrm{EC}$ & $\begin{array}{l}11.87 \\
(3.51)\end{array}$ & $\begin{array}{c}8.01 \\
(2.91)\end{array}$ & $\begin{array}{c}7.34 \\
(2.80)\end{array}$ & $\begin{array}{c}7.87 \\
(2.89)\end{array}$ & $\begin{array}{c}8.01 \\
(2.91)\end{array}$ & $\begin{array}{c}3.76 \\
(2.06)\end{array}$ & $\begin{array}{c}2.16 \\
(1.63)\end{array}$ & $\begin{array}{c}0.87 \\
(1.17)\end{array}$ \\
\hline Control & $\begin{array}{l}11.97 \\
(3.53)\end{array}$ & $\begin{array}{l}12.17 \\
(3.55)\end{array}$ & $\begin{array}{l}13.54 \\
(3.74)\end{array}$ & $\begin{array}{l}13.93 \\
(3.97)\end{array}$ & $\begin{array}{l}14.59 \\
(3.88)\end{array}$ & $\begin{array}{l}16.88 \\
(4.16)\end{array}$ & $\begin{array}{l}18.34 \\
(4.34)\end{array}$ & $\begin{array}{l}20.05 \\
(4.53)\end{array}$ \\
\hline$C D(p \leq 0.05)$ & NS & 2.30 & 2.48 & 2.63 & 2.19 & 3.23 & 2.67 & 2.19 \\
\hline
\end{tabular}

$*$ DBS - Days before spray, DAS - Days after spray

Figures in parenthesis are $\sqrt{\mathrm{X}}+0.5$ transformed values

NS- Non Significant

Imidacloprid (5.01 thrips/leaf/plant) and dimethoate (7.87 thrips/leaf/plant) were found best treatment in reducing the thrips population which were at par with each other. The next best treatment was carbosulfuran $(8.32$ thrips/leaf/plant) and novaluran $\quad(9.81$ thrips/leaf/plant).). Neem oil (10.23 thrips/leaf/plant) was found to be resistive against the thrips.

\section{Second spray}

Efficacy of the insecticides for the management of the pest revealed that all the insecticidal treatments at 1,7 and 14 days after spray were superior to control in reducing the pest population (Table 3 ). The observations recorded on $3^{\text {rd }}$ day after spray revealed that all the treatments proved significantly superior over 
control. Imidacloprid (2.79 thrips/leaf/plant) was found to be most effective treatment in reducing the thrips population which was at par with dimethoate (3.76 thrips/leaf/plant). The next best treatment was carbosulfuran (4.56 thrips/leaf/plant) and novaluran (6.67 thrips/leaf/plant). Among the insecticides, neem oil (8.71 thrips/leaf/plant) was found to be least effective against the thrips. The observations recorded on $7^{\text {th }}$ day after spray revealed that all the treatments proved significantly superior over control. Imidacloprid (1.08 thrips/leaf/plant) was found to be most effective treatment in reducing the thrips population which was at par with dimethoate (2.16 thrips/leaf/plant). The next best treatment was carbosulfuran (2.34 thrips/leaf/plant) novaluran (3.45 thrips/leaf/plant) and neem oil (6.87 thrips/leaf/plant). On $15^{\text {th }}$ day after spray revealed that all the treatments proved significantly superior over control. Imidacloprid (0.34 thrips/leaf/plant) and dimethoate (0.87 thrips/leaf/plant) were found best treatment in reducing the thrips population which were at par with each other. The next best treatment was carbosulfuran (1.12 thrips/leaf/plant) and novaluran (2.56 thrips/leaf/plant). The least effective insecticide against thrips was neem oil (3.32 thrips/leaf/plant). Our results are similar with that of Rani and Reddy (1999), who reported that imidacloprid $(0.1 \mathrm{ml} / \mathrm{l})$ was found to be superior to all other treatments in reducing the population of thrips, S. dorsalis on rose under polyhouse condition. Our results are in line with that of (Anonymous, 1992), who reported that Neem oil @ 2 per cent was found effective in controlling the thrips population on rose cultivated under polyhouse condition. The effectiveness of the neem oil might be due to toxic component azadiractin. These results are in agreement with the work of Luca (1982) who reported that oils caused higher mortality of the insects because of two possibilities such as blocking the spiracles causing asphyxiation and toxicant effect.

\section{References}

Anonymous, 1992. Pesticides from plants. Impact Ag. Bio-industry, pp. 19-23.

Anonymous,

2000. http://www.karnataka.com.statewiseareaand productionofflowers.

Gahukar, R.T. 2003. Factors influencing thrips abundance and distribution on rose flowers in central India. J. Entomol. Res., 27(4): 271-279.

Luca, Y.D.E., 1982. Products of vegetable origin that can be used against bruchids (Col.) (Attractants, antifeedents, deterrants, repellents, Leeshal). Frustula Ant., 2: 1929.

Park, J.D., Kim, S.G., Kim, D. and Cho, K. 2002. Population dynamics of Frankliniella occidentalis on different rose cultivars and flowering stages. J. Asia-Pacific Entomol, 5(1): 97-102.

Rani, J.B. and Mohan, J.N. 1997. Pest management in Horticultural crops. Inprogressive Floricultural Eds. I. S. Yadav and M. L. Chaudhary, House of Span, pp. 169-181.

Rani, J.B. and Reddy, J.G. 1999. Efficacy of selected insecticides against thrips Scirtothrips dorsalis Hood on rose in polyhouse. Pest Manag. Horti. Eco, 7(1): 54-58.

Satyanarayan, B.H. 2006. Ecobiology and management of thrips and mite of rose under polyhouse condition. M.Sc. (Agri) Thesis, University of Agriculture and Science, Dharwad (India).

\section{How to cite this article:}

Thanlass Norboo, Hafeez Ahmad, Suheel Ahmad Ganai, Nadeya Khaliq, Divya Chaand, Stanzin Landol and Sonika Sharma. 2017. Seasonal Incidence and Management of Thrips, Scirtothrips dorsalis (Hood) Infesting Rose. Int.J.Curr.Microbiol.App.Sci. 6(8): 101-106. doi: https://doi.org/10.20546/ijcmas.2017.608.013 